\title{
Museum of Contemporary Art by Artists
}

\author{
SCHLEICHER Alexander ${ }^{1,}$ * \\ ${ }^{1}$ Institute of Public Buildings, Faculty of Architecture, Slovak University of Technology in \\ Bratislava, Námestie Slobody 19, 81245 Bratislava 1, Slovakia \\ aalexander.schleicher@spde.sk
}

Keywords: Museum, Art, Museum Concept by Artists, Museum Design.

\begin{abstract}
Museum is type of building which among architectural work occupies a special place by its distinct function of documenting existence and progress of humankind, society and their environment. This is reflected in the outstanding architecture of these buildings. $95 \%$ of museum buildings arose after World War II. This authorizes us to talk about the museum as a "20th century phenomenon" especially of the second half of it. The unprecedented growth of museums after World War II - most of them are museums of art, especially contemporary art - entitles a question which is often discussed: What is an ideal museum like as an object serving for exhibiting art and what does an ideal exhibition space for contemporary art look like? This question had only been discussed among architects and museologists for a long time. According to the nature of contemporary art and because of the fact that alongside these two determinants the exhibiting artists who actively influence exhibition space and form the final spirit of the exhibition became an important element in creation of the museum; the question what is the artists' vision of the ideal museum is poignant. Answer to that question can be given by concepts of the ideal museum of contemporary art from the end of the $20^{\text {th }}$ century created by artists. The "Bilderbude" concept by Georg Baselitz, two projects "Ideal Museum" by Gottfried Honegger, "A Place Apart" by Marcia Hafif and also concepts of museums or opinions on a museum of contemporary art by other artists provide an idea of how the artists deal with and look on this problematic. The issue of museum of contemporary art perceived by the optics of artists definitely represents an interesting example of connecting functionality demanded by the artists, significant author's approach and philosophical ideas concerning the ideal museum of contemporary art.
\end{abstract}

\section{Museum Concepts - Thinking about Museum}

Museum concepts ${ }^{1}$ from the beginning of existence of museum buildings (in some cases even before considering a museum an individual specialized object or an institution) provide us the notice about the main themes which the actors of this problematic were dealing with at that time. While at the beginning in the museum concepts we can trace the effort to define an individual type of a museum building, an ideal museum; then we can see searching for a form which would be adequate to the building expression. Later especially in the 20th century until nowadays there have been solved more specific problems concerning the growth of the museum collections, expanding the functional structure of the museum, shape and form of the exhibition space etc. The museum topic such important personalities as for example Étienne-Louis Boullée, Le Corbusier or Ludwig Mies van der Rohe brought their contribution. The 20th century especially the 2 nd half of it, if we do not only consider the narrow present scope, brought an unseen growth of museum architecture. 95\% of museums arose after the World War II. [1] A great part of museums which were built in this period are museums of art, often presenting modern or contemporary art. This fact - emerging of such an amount of museums of contemporary art together with the changed form of visual art in the 20 th century - the importance of depicting and documenting function of art, which until then visual

\footnotetext{
${ }^{1}$ We do not have on our minds individual concepts of each museum which are a part of every object, but above all not realised philosophical or visionary concepts or realised museum buildings which brought conceptual thoughts that strong that they foretold and influenced the development of museum architecture for a long time ahead.
} 
art besides the aesthetical function was satisfying started to decrease, the artist were engaged in new themes, they experimented with new methods etc. - brings increasing effort of the artists to influence the final form of the exhibition spaces in the means of their specific demands and also to influence the form of the general form of the museum building. The artists more and more actively participate at creating the museum, they influence the form of the exhibition space and the exhibition itself - unlike in the past, when the museologist, curator was creating the exhibition by choosing from the collection, which he had at disposal and the exhibition was formed by them relatively independently from the artists - authors of the exhibits. The first artistic experiments, which balance on the edge of visual art and museum, have been occurring since the 20-ties of the $20^{\text {th }}$ century - let's mention for example El Lissitzky (Proun room, 1923), Kurt Schwitters (Merbau, 1923-37) or Marcel Duchamp (Boîte-en-valise, 1935-41), and they persist until nowadays. In the 70-ties Brian O'Doherty analyses from the point of view of an art theoretician but also an active artist the key exhibition space of the 2nd half of the 20th century, which he characteristically identifies as White Cube. Donald Judd - artist and at the same time a hostile critic of contemporary museum architecture (70-ties-80-ties) formulated his uncompromising point of view to the museum architecture as follows: "Forms' for their own sake, despite function, are ridiculous. One reason art museums are so popular with architects and so bizarre, is that they must think there is no function, the clients too, since to them art is meaningless. Museums have become an exaggerated, distorted and idle expression for their architects, most of whom are incapable of expression." In another text he posed the question: "Why are artists and sculptors not asked how to construct this type of building?" [2] As we can see the artists' opinion who seem to stay unheard in the museum and their needs stay unnoticed has full legitimacy and is very interesting for the problematic of museum and exhibition space. Beginning in the 70 -ties of the $20^{\text {th }}$ century these opinions are given more and more precise contours. While O'Doherty only comes with a theoretical essay on exhibition space (1976), D. Judd already presents his own idea of a museum even realised through the Marfa complex in Texas (1979/1986). Let's mention some other artists who form their ideas of an ideal museum in form of unrealised concepts. Some authors name their proposals after a bearing idea of their concept; others call them directly ideal, in the same way as it was in the beginning of the history of museum.

\section{Contemporary Art Museum Concepts by Artists}

\section{Georg Baselitz: Bilderbude.}

In the year 1977 Georg Baselitz presents his concept Bilderbude, which represents an architectural design of a museum. The object which was not realised was formerly designed as a temporary pavilion accommodating the paintings of four painters ${ }^{2}$ for the documenta 6 (1977) event. G Baselitz explains the concept at his lecture within Dortmunder Architekturtage, 1979. Starting with the motto: "Four walls and light from above or else, no painting on the wall" [3] the author presents himself as an active artist and from this position in the introduction develops ideas on the nature of a painter's work and autonomous nature of his creation which can exist on its own and needs not be viewed on any wall (hanging on the wall the painting according to Baselitz becomes a political instrument). Baselitz builds ideas on a museum - its only function is to create a protectory for a work of art and art viewing while no way should the museum influence by the context of perception the quality of the exhibits; it must enable viewing art in a simple, complete, unhindered and unpretentious way. He contemplates about perceiving museum by society - he criticizes its incompetency and nourishing the wrong opinions. Society doesn't understand the function and nature of museum and tries to turn it into a temple which according to Baselitz is outlived. He also criticizes the wide functional structure, so common presently which trivializes the museum. In these intentions he creates his concept which he himself characterizes: "Art contains no information, at least not more now than ever before; it is there to be looked at, not used in any other

\footnotetext{
${ }^{2}$ Bilderbude was planned for an exhibition of painters A.R. Penck, Jörg Immendorf, Markus Lüpertz and Per Kirkeby.
} 
way. For this, space, walls and light are required. The best light comes from above, the best room for this purpose has closed high walls, few doors, no side windows, light from above, no partitions, no baseboards, no base mouldings, no panelling, no shiny floors, and finally, no colour, either." [4] The simple minimalist form of Baselitz's concept consisting of four identical rooms for four artists without any hierarchy isn't surprising. Walls of exhibition spaces are high. Communications are minimalized and drawn out of the spaces - in plan view they form a cross defining particular exhibition rooms, entrances to the museum are on the corridor endings on the facade, entrances to the exhibition rooms are in the room corners at the inner corridor crossing. Lighting comes from above by the means of a pyramid-shaped skylight. The museum object volume is shaped into an elementary cubic form.
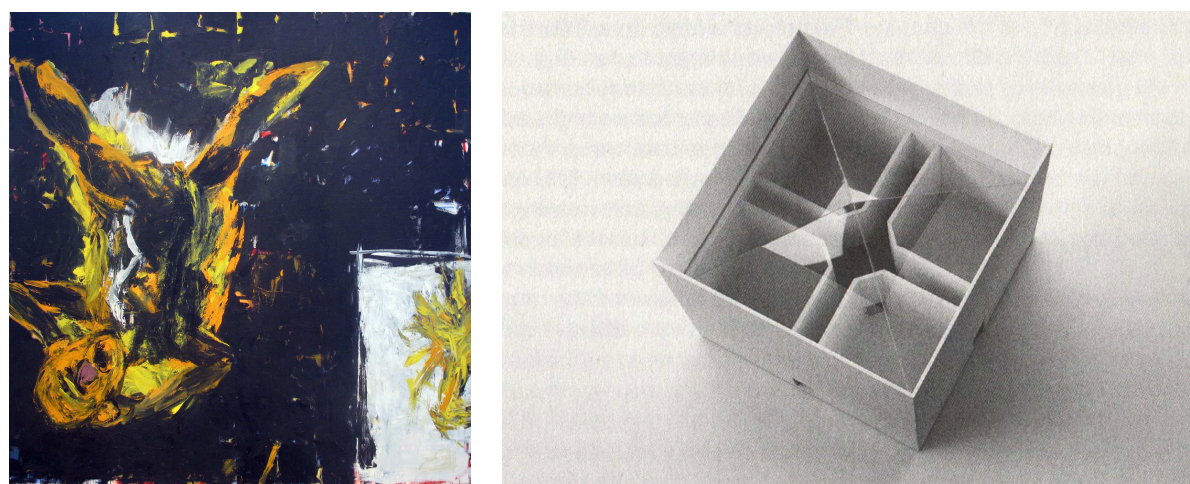

Fig.1 Georg Baselitz: Adler im Fenster (1982), Photo by Chris Ilsley [5]

Fig.2 Georg Baselit: Bilderbude (1978), Photo by Kunsthaus Bregenz [6]

The Museum as Imagined by the Artists. Espace de l'art concrete in Mouans-Sartous also addressed the question what should the museum look like according to the artists, when in 1997 mounting the exhibition entitled "The Museum as Imagined by the artists (Le Musée imaginé par les artistes)". They invited artists to provide statements, ideas and visions for museums and exhibition spaces and to design a Space for Art from their specific reference point as an artist. Based on the Museum for a Small Town by Ludwig Mies van der Rohe (1942) modestly-sized museum for concrete art rather than draw up detailed plans the artists were asked to come up with ideas and develop visions and utopias.

\section{Christoph Haerle: Ideal Project.}

Within the event Christoph Haerle came with his Ideal Project with a rather particular design elaborated in form of five models on a scale of 1:200 analysing individual spaces and a general concrete model on a scale of 1:50 corresponding with authors' work.
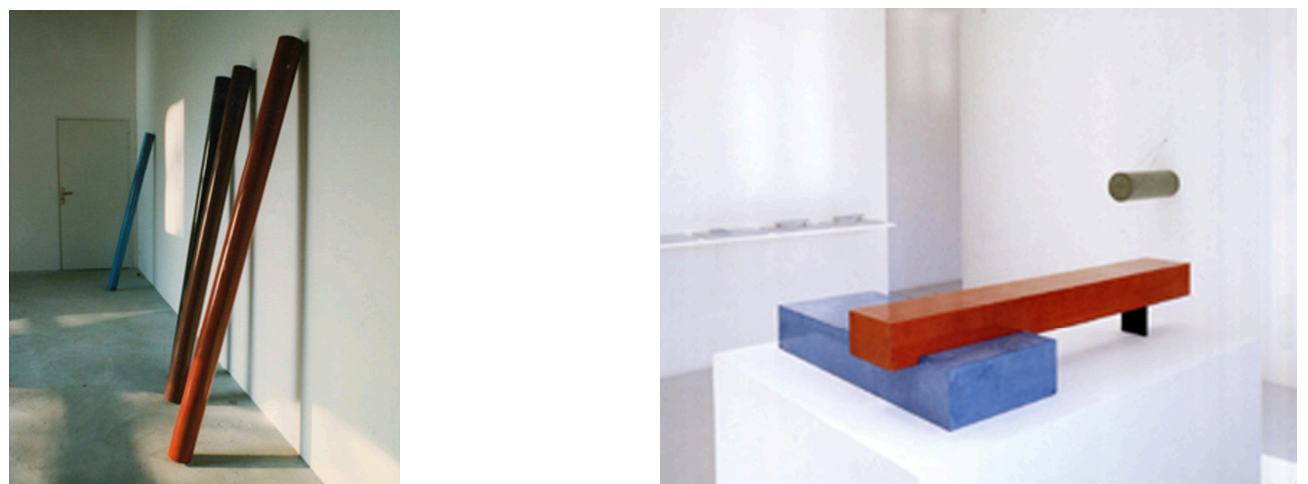

Fig.3 Christoph Haerle: Espace d’Art Contemporain, Demigny (1996) Photo: www.haerlehubacher.ch [7]

Fig.4 Christoph Haerle: Ideal Project (1997), Photo: www.haerlehubacher.ch [8] 
The volume configuration enables using lighting from above in the exhibition spaces in both of them, Haerle considers external wall perforations serving besides the lateral lighting especially to provide views into the outer room though; light entering purely from above would according to Haerle tend to be too sacred, inner space should have contact with the exterior. Interior space should be simple and white; the main body of the building should comply with the character intended in the model: monolithic, poured volumes made of dyed and sealed concrete that possesses the ability to react to light. According to Haerle museum "is a part and an expression of a conservative aspect of a society in a sense of "conservare", to preserve, to keep. In this way it represents something, the museum represents a society that is interested in time not just evaporating." [9]

Gottfried Honegger: Ideal Museum. Gottfried Honegger suggested two solutions for the Ideal Museum which can be seen as two variations of one concept. Varying of motives is a principle the artist also applies in his artistic work. In both cases the main body is divided into two main volumes, these are arranged above each other with a shift or rotation - in the first variation we see squares aligned with parallel orientation shifted along one of the axis in basic plane, in the second variation Honegger creates rectangles rotated at $45^{\circ}$. The volume offset and their relative shift in both cases creates a terrace designed as a garden with sculptures. The upper volumes use lighting from above through skylights positioned along external walls and in the centre - in case of the square plan there is a central square-shaped skylight, in case of the rectangular plan the skylight is also rectangle shaped with the same orientation as the volume. The upper volumes have fix space partitions in accordance to skylights location - in case of the square the rooms are arranged in a spiral aiming to the centre accentuated by the central skylight, in case of the rectangle the exhibition spaces and niches are lined up along the longitudinal axis. In both cases the author identifies the inner structure in the upper volume located museum space and rooms arrangement conservatively - as classical or traditional museum (in a modern building of course). The author thinks of the design as an object located in centre of a town creating "a kind of heart that beats for culture". [10] It is supposed to be a "meeting place" of which the author contemplates on two levels. The ideas start in a public space of a piazza in front of the museum, which should serve to culture and create "a lively urban environment" [10] - this is the first level of the space for human encounters. The second level of the meeting place is located inside the museum object - on a terrace created on the edge of volumes. Here a quiet and calm place to sit down, to discuss and to look at sculptures occurs. The object is not only a museum, it is a cultural centre - besides the museum it contains a library, a video-tape library, a cinema, a conference room, a book shop and a newspaper stand. Architecture should be anonymous, which means "without decoration and without any correcting interference". [10] This museum is not supposed to be a subject to fashion or any other personal influence. Architecture must stand out from the commonplace, it must be a kind of a symbol, a signal in the urban environment, yet it should have a plain and simple character. „My museum would no longer be a museum, but a place to learn how to see, to confront our history, to look, and to change up our souls." $[10]$
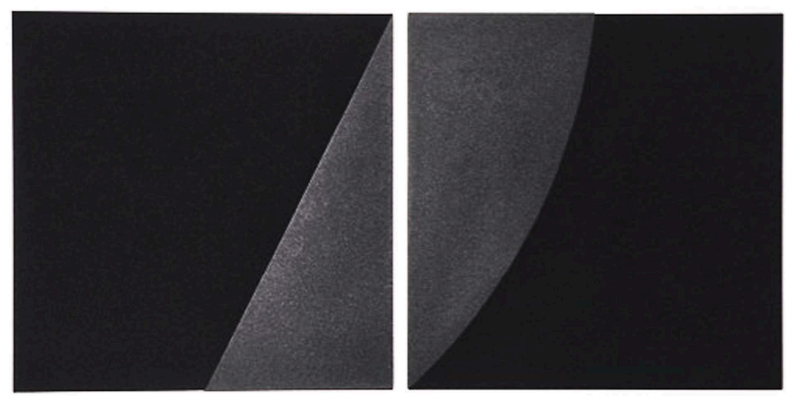

Fig.5 Gottfried Honegger: Tableau-Relief R 1237 (1997), Photo by Florent Darrault [11] 

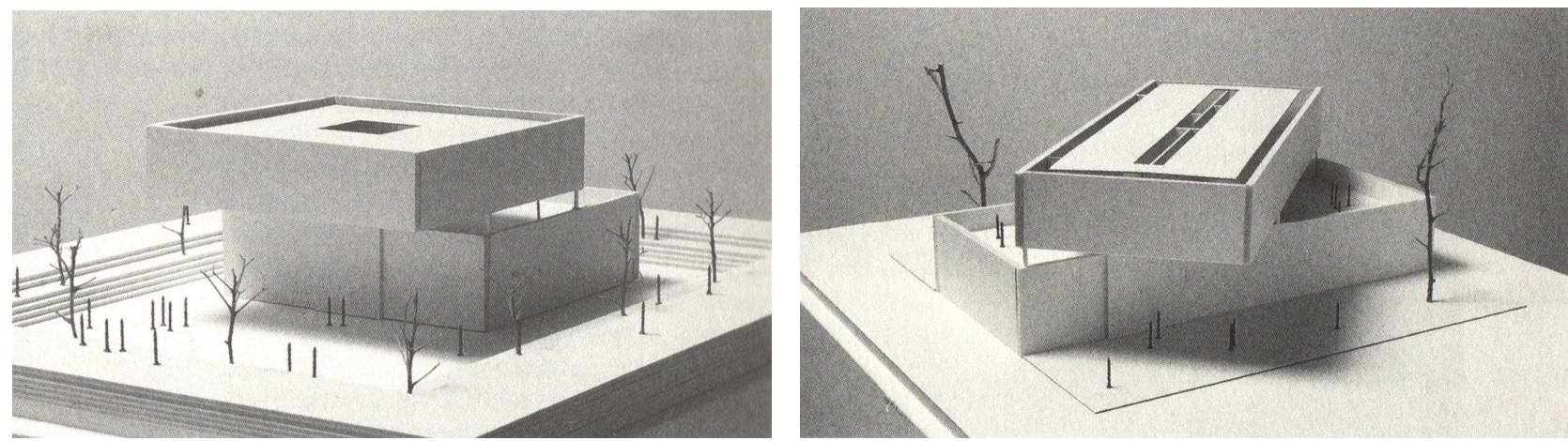

Fig.6 Gottfried Honegger: Ideal Museum, Alternative 1 (1997), Photo by Kunsthaus Bregenz [10] Fig.7 Gottfried Honegger: Ideal Museum, Alternative 2 (1997), Photo by Kunsthaus Bregenz [12]

Marcia Hafif: A Place Apart. Marcia Hafif named her project A Place Apart. The main idea of the concept is a contemplative effect of solitude and isolation. It is proved by situating the project after the author's words - in "a quiet place, far away from everyday life" [13], "an isolated place, perhaps within a forest". [14] The concept comes up also with another - inner form of separation, the author doesn't speak about isolation directly but it is an integral part of the design - the museum has a form of area created by five distinct, autonomous pavilions. The pavilions have basic forms of a cube, a cuboid, a cylinder or a truncated cone accessed by stairs or ramps. The object should be made of yellow or pink limestone. The structure implies an impression of an antique area. Pavilions are different in shapes of their inner spaces depending on the volume shape, the inner space is not an exact reflection of the pavilion shape though (the oval forms have straight walls inside). The inner structure of the pavilions also varies - in some cases there are monospaces, in other cases we see structured spaces creating diverse exhibition possibilities. The interiors should have different lighting levels achieved solely by the upper light through flat glass skylights with possibility of regulation by retractable canvas shades. The pavilion walls are not perforated by window openings the walls are solid, with white plaster. Floors are terra cotta. The place should according to Hafif serve for exhibiting, perceiving, and contemplating Concrete, Constructive or Radical painting or sculpture. "The place has only this purpose - no more". [15] This is supported by the museum only being a museum, nothing more - no additional café, bookstore or other functions, not even a parking place. To sustain the contemplative character and undisturbed atmosphere the museum should even be guide free.
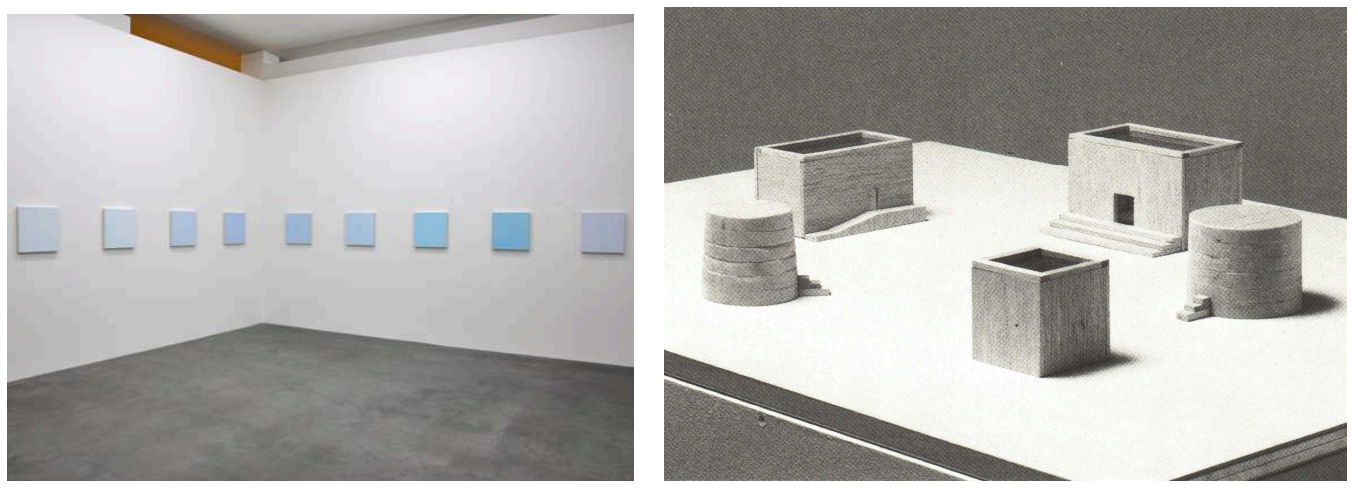

Fig.8 Marcia Hafif: Pale Painting: Blues (2009), Photo: www.marciahafif.com [16]

Fig.9 Marcia Hafif: A Place Apart (1997), Photo by Kunsthaus Bregenz [13]

Bernar Venet: Position of Four Right Angles. The Bernar Venet design called Position of Four Right Angles (Position de quatre angles droits) is an architectural expression of his same named wall installation from 1979, extended to his concept of an ideal museum. Playful and free structure of volumes creates a dynamic dialogue and various spatial situations of diversely formed courtyards - some of them open, some of them covered - which can be used for multiple purposes. The exterior ones as for example a garden with sculptures, the interior ones can be an extension of 
interior simply shaped spaces. In the interior the exhibition rooms are of various shapes and sizes rectangular or central, squared shape with perforations of the exterior walls by window openings, doors and diagonally shaped perforations. Additional openings by skylights along exterior walls enable upper lighting of exhibits placed along the walls. This kind of structure enables "classical museum situation". The colour scheme of the interior and exterior is white with accent to the light and shadow interplay of the concave and convex surfaces. This makes perceiving architecture easier and emphasizes the details of a simple concept. Venet's interest is to give architecture a subordinate role to the art and thereby have architecture serve art solely as an "exhibition wall". It is Venet's critique of "crazy excesses of many architects, who spend more time thinking about future generations than about having their work serve the artist". [17] Though this idea isn't a completed project, the concept brought by Venet in case of growing future demands allows the ideas about potential expansions of the museum by adding one or more square modules. Multiplication is namely one of the motives resonating through Venet's work.
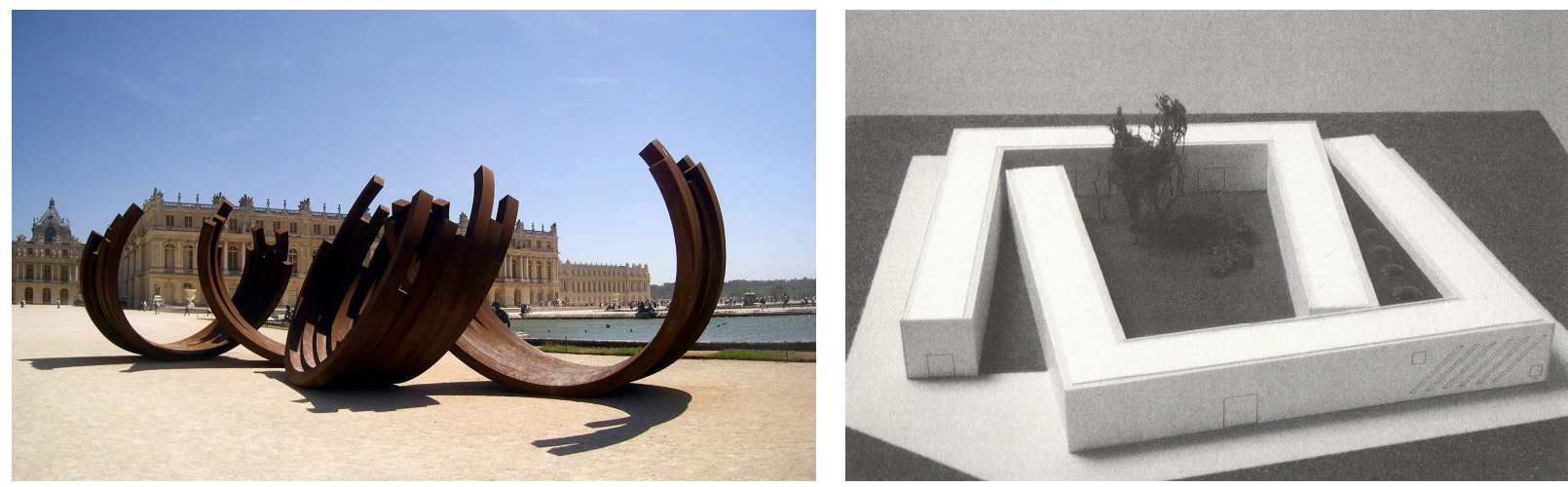

Fig.10 Bernar Venet: $219.5^{\circ}$ Arc $\times 28$ (2011), Photo by Groume [18]

Fig.11 Bernar Venet: Position de quatre angles droits (1997), Photo by Kunsthaus Bregenz [17]

Daniel Buren: Project for a Museum of Contemporary Art or "As you make your bed, so you must lie on it". Daniel Buren brought a solution - Project for a Museum of Contemporary Art or "As you make your bed, so you must lie on it". [19] The concept doesn't represent an actual design as we could see in more or less detailed form in previous cases, it is more a vision, it outlines a modus operandi of how an ideal museum of contemporary art should be created. It is a long-term plan for 10 or even more years involving intelligent people absolutely convinced of the project. After choosing a plot of land large enough and in good location it is necessary to address chosen artists, the maximum number is limited by Buren to 36. These will design objects meeting set regulations - maximum ground surface $\left(200 \mathrm{~m}^{2}\right)$, maximum height $(9-10 \mathrm{~m})$ embodying 1-3 floors etc. The minimal dimensions are not limited.
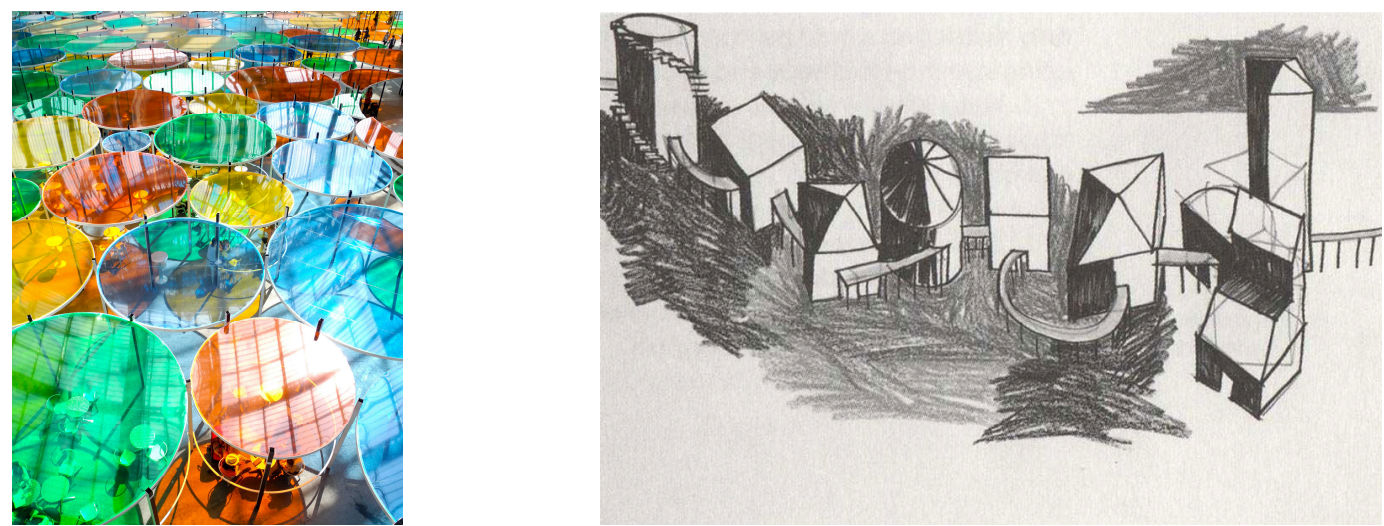

Fig.12 Daniel Buren: Installation at Monumenta, Paris (2012), Photo by Jeanette [20]

Fig.13 Daniel Buren: Project for a Museum of Contemporary Art (1997),

Photo by Kunsthaus Bregenz [21] 
The museum manager will provide technical aspects of the project; the strict demand for the artists is to create designs which are able to be built. Each object will correspond to artist's work and they can be ordered for example in a form of a spiral with the starting point in the centre of the plot and entwining to the its verge. Buren says the museum won't serve for temporary, short-term exhibitions. It should be a permanent installation with a relationship to particular artists who embodied the museum. He warns of one more thing: "And, finally, the invited artists may not call in architects to plan their room, apart from technical support." [22] This opinion clearly reflects some artists' view to architects and museum buildings created by them.

François Morellet: Museum of Concrete Art. François Morellet despite his indisputable qualities as a minimalist, light art and three-dimensional installation artist doesn't feel to be authorized to design an architectural concept of a museum. He develops theoretical ideas on a museum; he starts with the title and his own experience. He considers the term "museum" too serious or even boring "despite all the joy, despite all the discoveries that I have been lucky to have made in very many museums". [23] Entitling the museum as a "room" ("espace") as used in case of Espace de l'art concrete in Mouans-Sartous is according to Morrelet more suitable or at least less archaic. Morrelet doesn't consider Greek temples or cathedrals - as the museums of $19^{\text {th }}$ century seem to him, to be suitable for a concretists exhibition nor does he approve $20^{\text {th }}$ century museum architecture where the art falls into oblivion, lands up subordinate or its presentation is prevented by slanted or bent or otherwise deformed rooms, walls made of unplastered concrete, marble or glass or instead of walls hanging panels etc. He rediscovers a "commonplace" architecture for a museum rooms that he describes as flats or artists' ateliers, spaces "with pure white walls that reach from the floor to the ceiling, without base mouldings, and in which nails can be put". [23] According to Morrelet, his works which were created in "commonplace" rooms, really feel comfortable in such "commonplace" architecture. The artist closes his ideas by thoughts of two elementary functions of a museum of contemporary art: "The first function of a museum of contemporary art is to convey joy. Especially and above all the joy of discovering new works, new movements, new culture etc..." and further he continues - "The second function of a museum naturally continues to be that you can seek out masterpieces there again (until you're sick of them), which you have already discovered". [24] Morrelet closes this discourse and comes back to the beginning: "It is very clear that, as a visitor, I also prefer museums which have a discrete or even commonplace architecture" [24] and adds up an illustrative picture having a character of a protest.
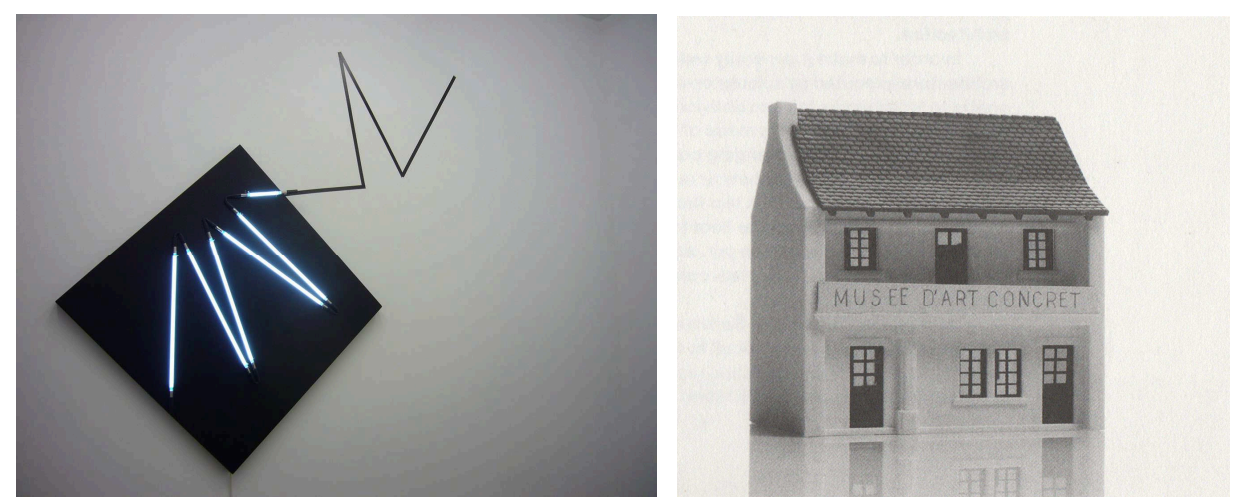

Fig.14 François Morellet: Négatif $n^{\circ} 8$ (d'après $\pi$ Strip-teasing $1=10^{\circ}$ sur la pointe) (2005), Photo by Natalie Hegert [25]

Fig.15 François Morellet: Musée d’art concret (1997), Photo by Kunsthaus Bregenz [24]

\section{Similarities and Dissimilarities}

What is the artists' opinion on the museum of contemporary art then? What do the concepts have in common and what on the other hand different? Ideas on an ideal form of a museum differ. Many 
aspects are perceived differently by different authors - from the extreme points of view for some locating the museum in an isolation to achieve a contemplative character and uninterrupted art viewing is important (Hafif), others on the other side of the spectrum see the museum as a cultural centre which is a part of a lively urban environment and creates a heart beating for culture (Honegger). The opinion on contemplativeness, undisturbed exhibits viewing and traditional museum standstill is also connected with some artists' view on functional structure - while some consider the museum a basis for many other functions and talk about a cultural centre (Honegger), others see the museum as the only possible and admittable function (Hafif), or even consider adding other functions trivialising the museum topic (Baselitz). Besides exhibits viewing in some cases the related element of discovering and educational importance of the museum is accentuated (Honegger, Morrelet). Some artists create a museum in form of a plain solitary single volume divided in the interior though (Baselitz), others' designs form more structured volumes (Haerle, Honegger, Venet), the most extreme have the form of pavilions - interconnected (Buren) or radically isolated in form of basic shapes organised into an ancient-like complex (Hafif). Despite the structure of the complex as well as the used material (limestone) reminding of antique, the form of the particular objects is contemporary with only few historical reminiscences. Though refusing museums as temples - the temple principle in spirit of a historical object is refused (especially Baselitz, Morrelet), sacrality is more or less present in each case - in physical form by the volumes structure and used materials (Hafif) or only spiritually, internally in the contemplativeness, viewing and discovering inside the museum (Hafif, Baselitz, Morrelet, Honegger).

By all the artists the theme of giving priority to art and admitting absolute dominance of the exhibits persists - museums serves the art not the other way round. This motive mostly resonates in the interior and in the environment that the artists create for the exhibits - here a rare accordance was found: solid white walls (in some cases with views to the exterior though) and preferring the ideal lighting from above. Despite accentuating the higher importance of the exhibits than of the architecture of a museum and also the fact that in case of architects the artists strictly refuse strong authors' concepts with expressive results, they do not avoid same approach when designing themselves (and it is good so). In case of the artists coming up with an author's concept in form of an object (Buren) we can question the legitimacy of this kind of approach by the artist as the author of architecture. The strong effect is present especially thanks to the concretist nature of work based on elementary geometrical principles of the majority of them. The concepts which have the form of an architectural design are architectonically very cultivated.

As designs on the verge of reducing architectural elements to an inevitable minimum we can classify Macia Hafif's design, which in a large extent relates to the nature of her art work; but surprisingly also the design of Georg Baselitz, who doesn't belong to the concretists group and is classified according to the critics' opinion as neoexpressionist or postmodernist. He brings up the minimalism not corresponding with his art work as a manifest and this makes his contribution even more interesting. Within the architectural minimalism Baselitz too doesn't deny being an artist and applies art quotation on an architectural element - both sides of the entrance doors to the exhibition rooms are for him canvases for paintings and therefor he covers them with his artwork.

We will not find a universal consistent approach to the museum theme among the artists as we won't find it among the architects. In the artists' ideas on an ideal museum of contemporary art as well as the whole museum problematic through we can sense great plurality. It is this plurality that the most precisely characterizes the museum theme since its beginning and especially in its present times. 


\section{References}

[1] S. Macdonald, Expanding Museum Studies: An Introduction, in: S. Macdonald (Ed.), A Companion to: Museum Studies, Wiley-Blackwell, Oxford, 2011, p. 4.

[2] E. Köb, The Voice of The Artist, in: E. Köb (Ed.), Museum architecture: Texts and Projects by Artists, Buchhandlung Walter König, Cologne, 2000, p. 7.

[3] G. Baselitz, Bilderbude 1977, in: E. Köb (Ed.), Museum architecture: Texts and Projects by Artists, Buchhandlung Walter König, Cologne, 2000, p. 11.

[4] G. Baselitz, Bilderbude 1977, in: E. Köb (Ed.), Museum architecture: Texts and Projects by Artists, Buchhandlung Walter König, Cologne, 2000, p. 13.

[5] Information on https://www.flickr.com/photos/301202/7035256311

[6] G. Baselitz, Bilderbude 1977, in: E. Köb (Ed.), Museum architecture: Texts and Projects by Artists, Buchhandlung Walter König, Cologne, 2000, p. 15.

[7] Information

on

http://www.haerlehubacher.ch/kunst/3_ausstellungen/8_espace_art_contemp_demigny/index.html

[8] Information

on

http://www.haerlehubacher.ch/kunst/3_ausstellungen/6_museum_bregenz/index.html

[9] Ch. Haerle, Ideal Project 1997, in: E. Köb (Ed.), Museum architecture: Texts and Projects by Artists, Buchhandlung Walter König, Cologne, 2000, p. 39.

[10] G. Honegger, Two Projects for an Ideal Museum 1997, in: E. Köb (Ed.), Museum architecture: Texts and Projects by Artists, Buchhandlung Walter König, Cologne, 2000, p. 47.

[11] Information on https://www.flickr.com/photos/workflo/14767343924

[12] G. Honegger, Two Projects for an Ideal Museum 1997, in: E. Köb (Ed.), Museum architecture: Texts and Projects by Artists, Buchhandlung Walter König, Cologne, 2000, p. 46.

[13] M. Hafif, A Place Apart 1997, in: E. Köb (Ed.), Museum architecture: Texts and Projects by Artists, Buchhandlung Walter König, Cologne, 2000, p. 40.

[14] Information on http://www.marciahafif.com/inventory/place.html

[15] M. Hafif, A Place Apart 1997, in: E. Köb (Ed.), Museum architecture: Texts and Projects by Artists, Buchhandlung Walter König, Cologne, 2000, p. 41.

[16] Information on http://www.marciahafif.com/inventory/pap.html

[17] B. Venet, Position de quatre angles droits 1979/1997, in: E. Köb (Ed.), Museum architecture:

Texts and Projects by Artists, Buchhandlung Walter König, Cologne, 2000, p. 104.

[18] Information on https://www.flickr.com/photos/groume/5794382719

[19] D. Buren, Project for a Museum of Contemporary Art 1997, in: E. Köb (Ed.), Museum architecture: Texts and Projects by Artists, Buchhandlung Walter König, Cologne, 2000, p. 20.

[20] Information on https://www.flickr.com/photos/justjeanette/7322170196

[21] D. Buren, Project for a Museum of Contemporary Art 1997, in: E. Köb (Ed.), Museum architecture: Texts and Projects by Artists, Buchhandlung Walter König, Cologne, 2000, p. 22.

[22] D. Buren, Project for a Museum of Contemporary Art 1997, in: E. Köb (Ed.), Museum architecture: Texts and Projects by Artists, Buchhandlung Walter König, Cologne, 2000, p. 21.

[23] F. Morellet, Museum of Concrete Art 1997, in: E. Köb (Ed.), Museum architecture: Texts and Projects by Artists, Buchhandlung Walter König, Cologne, 2000, p. 69.

[24] F. Morellet, Museum of Concrete Art 1997, in: E. Köb (Ed.), Museum architecture: Texts and Projects by Artists, Buchhandlung Walter König, Cologne, 2000, p. 70.

[25] Information on https://www.flickr.com/photos/nattyboom/2955610080 